\title{
Article \\ SCHOOL IN EARTHQUAKE THREAT: SCHOOL BASED DISASTER PREPAREDNESS MODEL IN INDONESIA
}

\section{Avid Leonardo Sari}

Study Center for the Faculty of Social and Political Sciences, Sunan Gunung Djati State Islamic University, Bandung, Indonesia. Avidleonardo@uinsgd.ac.id

\begin{abstract}
This research was conducted on the Maribaya Timur school community in Lembang Subdistrict, West Bandung Regency, Indonesia, which is an active community in the area that is threatened by the potential for earthquake disasters due to the active Lembang fault. Disaster risk reduction efforts are pursued through increasing school-based preparedness that involves members of the school community, surrounding communities and various institutions that are associated with reducing the risk of school-based earthquake. Increasing preparedness against earthquakes focuses more on aspects of capacity building of school communities in reducing disaster risk, while aspects of vulnerability and threats have not been the focus of disaster risk reduction. The steps taken refer to the element of preparedness by aligning with the conditions, needs and potential that exist in the school community. Theoretically, if the school community has preparedness to face an earthquake disaster, the risk of earthquake disaster in the school community will be reduced so that it can minimize losses, victims and suffering that will be caused by the earthquake disaster.
\end{abstract}

Keywords: Disasters, Preparedness, Lembang Fault, Community Base, School

\section{Introduction}

The Indonesian archipelago is on the equator, tectonically located on four active earth crust plates: the Indo-Australian plate is located in the south which is relatively northward and lepengpasifik and the Philippine microplate in the east which tends to move towards the west and both resting under the Asian plate southeast which is part of the large plate of Eurasia.

This fact rarely happens on earth, according to Russell Miller (1990) in Engkon K. Kertapati (2010). It is estimated that in the next 100 years, the Indonesian coastal area will be hit by the IndoAustralian plate and will only leave Sumatra, Bangka and several small islands. others. In general, in the world, the collision of the earth's crust only involves two plates, but in Indonesia it involves 4 plates at a time so that it becomes very complicated in its tectonic state.

According to the United Nations International Strategy for Disaster Reduction (UN-ISDR) Indonesia is ranked third in the world's most earthquake prone. This is an affirmation for the Indonesian people to further enhance disaster management efforts. The 2004 earthquake and tsunami that struck the provinces of Aceh and Nias made the Indonesian state aware of comprehensive disaster management, so in response to this in 2007 Law No. 24 concerning Disaster Management was born as well as being the initial foundation professional disaster management measures in Indonesia.

Based on the disaster vulnerability index map released by the National Disaster Management Agency (BNPB), it shows that West Java Province is the province with the highest level of disaster vulnerability in Indonesia, starting from the very diverse distribution of potential disasters, population numbers and geographical conditions.

Activity in areas prone to earthquake disasters is a reality that must be faced by people who live around the active fault Lembang. The active fault of Lembang which stretches for 22 Kilometers $(\mathrm{Km})$ 
from Maribaya, Cibodas to Cisarua in the north of Padalarang District, West Bandung Regency. Active faults are classified as normal faults and keep the potential threat of an earthquake with a magnitude of 6.7 SR. Lembang's active fault has caused earthquakes in the last five years, namely in 2003 and 2011. On August 28, 2011 an earthquake occurred in Cisarua District, West Bandung Regency with a magnitude of 3.3 on the Richter Scale (SR) with an epicenter depth of $10 \mathrm{Km}$. The earthquake was indeed of low magnitude but caused considerable damage to several houses, this shows that the Lembang fault is a real threat / danger for people living in the Lembang fault area especially and people living in the Bandung Raya area (Kabupaten Bandung, Kabupaten West Bandung and the City of Bandung) in general.

Based on the scientific publication of the thesis of the Earth Science Study student at the Bandung Institute of Technology, Didik Wahju Widjaja stated that earthquakes originating from the active Lembang fault could cause damage not only to the Lembang region, but also potentially cause damage to the Bandung Regency and Bandung City. Earthquakes do not become a disaster if they do not cause ruins that can cause suffering to humans. Earthquakes do not produce direct harm to humans because earthquakes are only earth vibrations, which can endanger humans if the earthquake causes damage and ruins of buildings that can befall humans. These ruins have resulted in loss of life and other suffering.

Indonesian people are not too familiar with the occurrence of earthquakes, but efforts to reduce the risk of earthquake disasters have not become a culture in life. Earthquake risk reduction activities can minimize damage, losses or sufferings caused by an earthquake. The most vulnerable elements of society in the event of a disaster are children, especially children in their daily activities at school. In a day the average child can spend 8 hours in school, so the school can be categorized as a disasterprone place for children because they do not have school-based disaster risk reduction activities (PRBBS).

The pre-disaster phase is an important and very decisive phase in every event that occurs. Good disaster risk reduction management can improve community preparedness in the face of disasters that have an impact on the reduced risks and effects of disasters that occur, as well as the ability of the community to recover and rise again after the disaster has passed.

In the pre-disaster phase, children actually have great potential to be able to play a role in disaster risk reduction activities that exist in their environment, meaning that before the disaster children are an effective medium in disseminating disaster prevention and prevention efforts, children with innocence and sincerity can easily absorb all the information conveyed especially if the information delivered is packaged well and interactively using the school setting as its community.

Learning from a 7.8 magnitude earthquake that occurred in Shincuan Province, China in 2008 which resulted in thousands of students and teachers dying at school. Some of the 19,509 victims found in the collapsed class were children or students. Meanwhile 124 school rooms in four Tarutung Subdistricts of North Tapanuli Regency were damaged by an earthquake measuring 5.5 on the Richter Scale which hit the area on June 14, 2011, fortunately the earthquake occurred before school hours so that it did not cause casualties to school students. The issue of school-based disaster risk reduction has been initiated by the United Nation International Strategy for Disaster Reduction (UN-ISDR) through the world campaign program on disaster risk reduction in 2006-2007.

On September 2, 2009 there was an earthquake centered in Tasikmalaya District with a magnitude of 7.3 SR and caused damage to the road to Bandung City, Bandung Regency and West Bandung Regency. Based on data released by BNPB about the number of heavily damaged houses damaged by the earthquake in West Bandung Regency, West Java Province, it was recorded that 56 houses were severely damaged in Langensari Village and 12 heavily damaged houses in Mekarwangi Village. The above information further reinforces that school-based disaster risk reduction (PRBBS) activities are an absolute thing to do. Especially for schools that are right above active faults such as schools that are above the active Lembang fault.

To meet the needs of Researchers, school-based earthquake disaster risk reduction is carried out for schools in the active fault area of East Maribaya Lembang, efforts have been made to reduce disaster risk through the Earthquake Alert School program, hereinafter abbreviated as SESAPA in East Maribaya Region, Lembang District West Bandung Regency. 
Through activities conducted by researchers, school-based earthquake disaster risk reduction efforts have been carried out through a program popularized by the term "Sesapa" (Earthquake Alert School). This program aims to build school community preparedness in the face of the threat of an earthquake. The stages of preparedness that have been carried out include; disaster risk assessment, making an earthquake disaster risk map, determining the evacuation route and installing evacuation signs, building an early warning information system, disaster education and training. While the stages of preparedness that have not been implemented are compiling contingency plans, conducting internal and external coordination, mobilizing resources, compiling response mechanisms, and conducting routine rehearsals / simulations.

To realize the preparedness of the school community in facing the potential for earthquake disasters, the study was interested in making improvements to the school-based earthquake preparedness model. This improvement was pursued through research with a participatory action research model (parcipatory action resarch) so that community members actively participated in discovering, evaluating and evaluating the condition of the community in the face of earthquake preparedness. Then a joint action plan is prepared to be implemented in accordance with the preparedness element that has not been implemented in the hope that it will improve the preparedness model to face school-based earthquakes. The implementation of this research will be focused on the Mekarwangi Lembang Middle School and High School community because it has the highest level of disaster risk among other school communities.

\section{Method}

The method used in this study is an action research method with a qualitative approach. Silalahi (2006) says that in qualitative research inductive logic applies. Categories arise from informants or participants when research is ongoing (emerging design categories during the research process) and not identified by researchers before the research activities are carried out. This happens because the community is still relatively foreign to the intervention model implemented and the research process is carried out at the same time as the implementation of the intervention model.

This category provides "context-bound" information enrichment that influences patterns or theories that help explain phenomena (patterns, theories developed for understanding). The intended category includes the values and norms regarding life in the community. These values and norms have their own uniqueness and distinctiveness which cannot be explained by general theories.

The choice of qualitative research methods is based on the reasons:

a. Assumptions used are reality that is seen as something subjective and the researcher wants a closer relationship with the informant or participant.

b. Research problems must be explored because there is little information available on this matter.

c. Variables are not widely known and attention must be focused on contexts that can form an understanding of the phenomenon being studied.

The research classification used is participatory action research (participatory action research) with the aim of improving and perfecting the intervention model that was previously carried out during the practicum. Proof of the accuracy of the information obtained in qualitative research is done by triangulating data through sources, techniques and time. According to Kemmis (1983), action research is an attempt to try out ideas into practice to improve or change something to get a real impact from the situation. Kemmis and Taggart (1988), states that action research is a form of self-reflective research that is collectively carried out by researchers in social situations to improve reasoning and fairness of practice and to the situation in which these practices are carried out.

\section{Results and Discussion}

\section{a. Early Model of Preparedness for School-Based Earthquake Disasters.}

The capacity building program of the school community in the face of earthquake disasters in the school community that is threatened by the potential for an earthquake disaster due to the active fault Lembang, West Bandung District, Lembang is based on the lack of capacity or ability of the school community in the face of earthquake disasters. The low capacity of the community in dealing with earthquake disasters makes the school community has a high level of disaster risk. Mekarwangi school community is the school community with the highest level of earthquake risk. 
The capacity of the mekarwangi school community to deal with disasters is very low, so a program was established which aimed to increase capacity in the face of earthquake disasters. The program was formulated with the school community and was given the name of the program namely the Earthquake Alert School (Sesapa). The spirit of this program is an effort to improve preparedness in the face of school-based earthquake.

The need to increase community capacity / capability in the face of earthquake disasters was obtained from an assessment in the field that there is an active lembang fault that has the potential to cause earthquakes with strengths ranging from 6.0 to 7.0 Sr. Data from the Center for Volcanology and Geological Disaster Mitigation (PVMBG) of the Ministry of Energy and Mineral Resources (ESDM) through its official publication through GeoMags magazine states that Lembang Active Fault is a fault that stores the potential of earthquakes and moves $0.3-2 \mathrm{~mm} /$ year. The movement of the active lembang fault causes the earthquake to occur someday.

The Mekarwangi school community is located right above the active lembang fault and is approximately 100 meters from its peak, Mount Batu lembang. In addition to the high threat level, the Mekarwangi school community also has a high level of physical, social, economic and environmental vulnerability, and this condition is exacerbated by the low level of capacity or capacity of the community in the face of the threat of an earthquake.

Based on these three aspects, it was concluded that the level of earthquake risk in the school community was very high. Participatory assessment refers to community-based and nonparticipatory disaster risk analysis through informal talks and observations In connection with the information mentioned above, a plan for increasing community capacity / capability was carried out in response to the earthquake disaster. This capacity increase covers a variety of aspects and passes through several stages of the implementation of activities. To support the implementation of the intervention plan, the Earthquake Alert School Community Team was formed, called TKK Sesapa. Sesapa TKK is a form of community organizing to build community member participation to overcome problems or fulfill their own needs.

The interventions carried out to increase the capacity of the Mekarwangi school community in dealing with earthquake disasters are as follows:

1) Community Commitment to Building Preparedness.

2) Earthquake Disaster Risk Assessment.

3) Organizing and Coordination.

4) Increasing knowledge and building community awareness.

5) Assessment of dangerous objects / buildings during an earthquake.

6) Preparation of sketches of maps of Disaster Risk Areas and Evacuation Pathways

The source system involved in implementing activities comes from the school community as the target group. The strategy is carried out by implementation and collaboration. The tactic is to strengthen capacity with orientation to community participation and organization. Monitoring and evaluation of activities is carried out by looking at processes, outputs and results that refer to participatory monitoring and evaluation. The initial model / program chart for the condition after practicum as below: 
Picture 1

Early Model of School Based Earthquake Disaster Risk Reduction Through the Earthquake Alert School Program in the Mekarwangi Lembang School Community

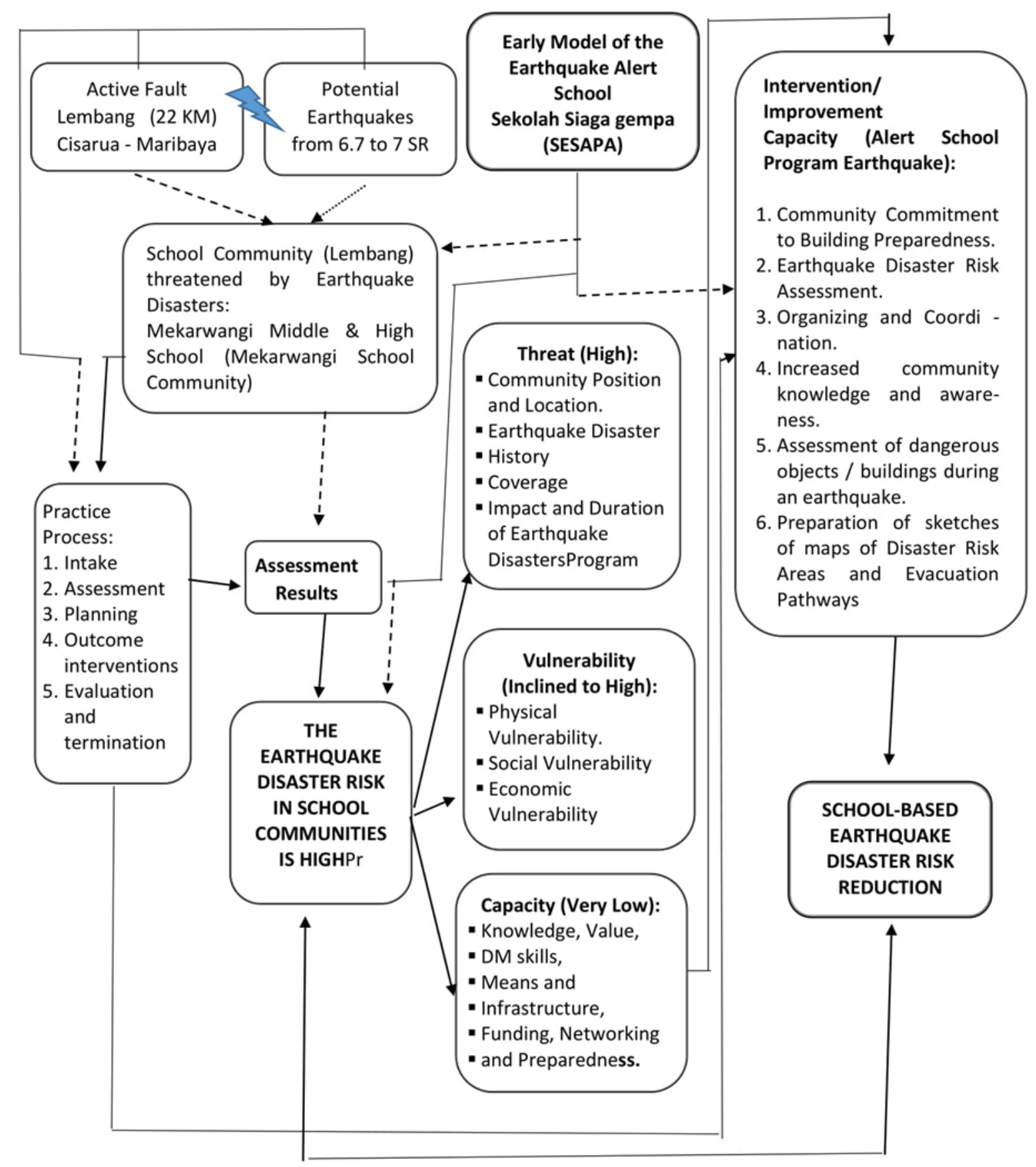




\section{b. Final Model of Preparedness for School-Based Earthquake Disasters.}

The initial conditions at the research location showed that school-based disaster preparedness in the Mekarwangi school community was not yet complete. The existing development shows that the indicator of preparedness that is owned by the school community is only $50 \%$. The Earthquake Alert School Group Working Team has not yet carried out any further activities, this is due to a shortage of Human Resources and Time owned by members of the Earthquake Alert School Team Work Team to continue the preparedness efforts that have begun.

The first step to knowing and understanding the development of the initial conditions of the preparedness of the Mekarwangi school community in the face of earthquake disasters is the assessment process in this study. The researcher conducted in-depth interviews, observations and discussions with the administrators and members of the Earthquake Alert School Working Team to obtain data and information about the reality. Documentation studies were carried out to look at reports, notes or other things documented by the Earthquake Alert School Team Working Team.

Observations are made to see the activities carried out by community members in interacting while in the school environment. This was done to obtain physical data and activities from the Mekarwangi School Community. Based on the results of the above data collection with both the management and members of the Earthquake Alert School Team and the researchers themselves, it can be seen that the lembang mekarwangi school community still has some limitations in continuing the efforts to prepare for the earthquake disaster.

School-based disaster preparedness has not been continued yet by the Earthquake Alert School Team Team due to the absence of key actors who focus on managing the continuation of activities. Coordinator of the Group Work Team which is the Head of the The Mekarwangi Middle School and Senior High School are busy with responsibility at school, while students who are members of the core team of the Earthquake Alert School Team have not had the initiative to implement it. Because from that the researcher plays the role of motivator and companion, which aims to revive awareness and enthusiasm of members of the Earthquake Alert School Team to continue the efforts of community preparedness.

After motivating the members of the Group Work Team to want to continue their preparedness in response to the school-based disaster that they have begun, the next step is to facilitate followup planning (RTL) which is the next stage of capacity assessment. In these activities from various ideas of meeting participants. RTL as a priority includes aspects of activities / program management, namely the socialization of the Earthquake Alert School and details of the task of the Earthquake Alert School in the community, data collection for evacuation evacuation locations, aspects of relationships with other parties, namely the existence of the Lembang District Earthquake Alert School with other parties, sustainability aspects The organization is the activity of submitting reports on the activities of the Earthquake Alert School to the Government of Lembang District and the administrative and financial aspects, namely the establishment of the Lembang District Earthquake Alert School secretariat.

In realizing the follow-up plan (RTL) that has been prepared jointly by the management and members, the next step is to implement the activity. The strategy carried out was collaboration, meaning working directly with the management and members of the Lembang Earthquake Alert School and with a source system outside the group, in this case the Alhidayah Lembang Mosque, Lembang Football Field, Lembang District Government and several existing local organizations. The tactic was carried out by implementing activities directly in the field and aimed at increasing the capacity of the management and members of the Lembang District Earthquake Alert School.

Activity monitoring and evaluation is the next stage of capacity assessment assessment. In this activity the researcher acts as a facilitator. The monitoring and evaluation phase aims to determine the results of the implementation of activities and the final condition of capacity

Lembang District Earthquake Alert School after efforts to improve practice. The known aspects of monitoring and evaluating these activities include aspects of the results achieved, supporting factors and inhibiting factors and further suggestions. 
While the aspects seen in the final condition include improvements only to the management aspects of activities / programs, administrative and financial aspects, aspects of relationships with other parties and the sustainability aspects of the organization. The final condition shows that there is a positive increase through increasing the practice of five activities on the four aspects of organizational capacity that have been mentioned.

The result of the improvement from the initial condition of the capacity of the Lembang District Earthquake Alert School to the final condition shows that there is a clear secretariat and address to be known by various parties, the Lembang District Earthquake Alert School has a regular schedule of meetings every three months. jointly damaged planning, Earthquake Alert School has shared information with other parties through socialization The existence of the Lembang District Earthquake Alert School has received financial support for disaster risk reduction activities. The final model / program chart at the time of research as below:

Picture 1

Final Model of School Based Earthquake Risk Reduction Disaster Through the Earthquake Alert School Program in the Mekarwangi Lembang School Community

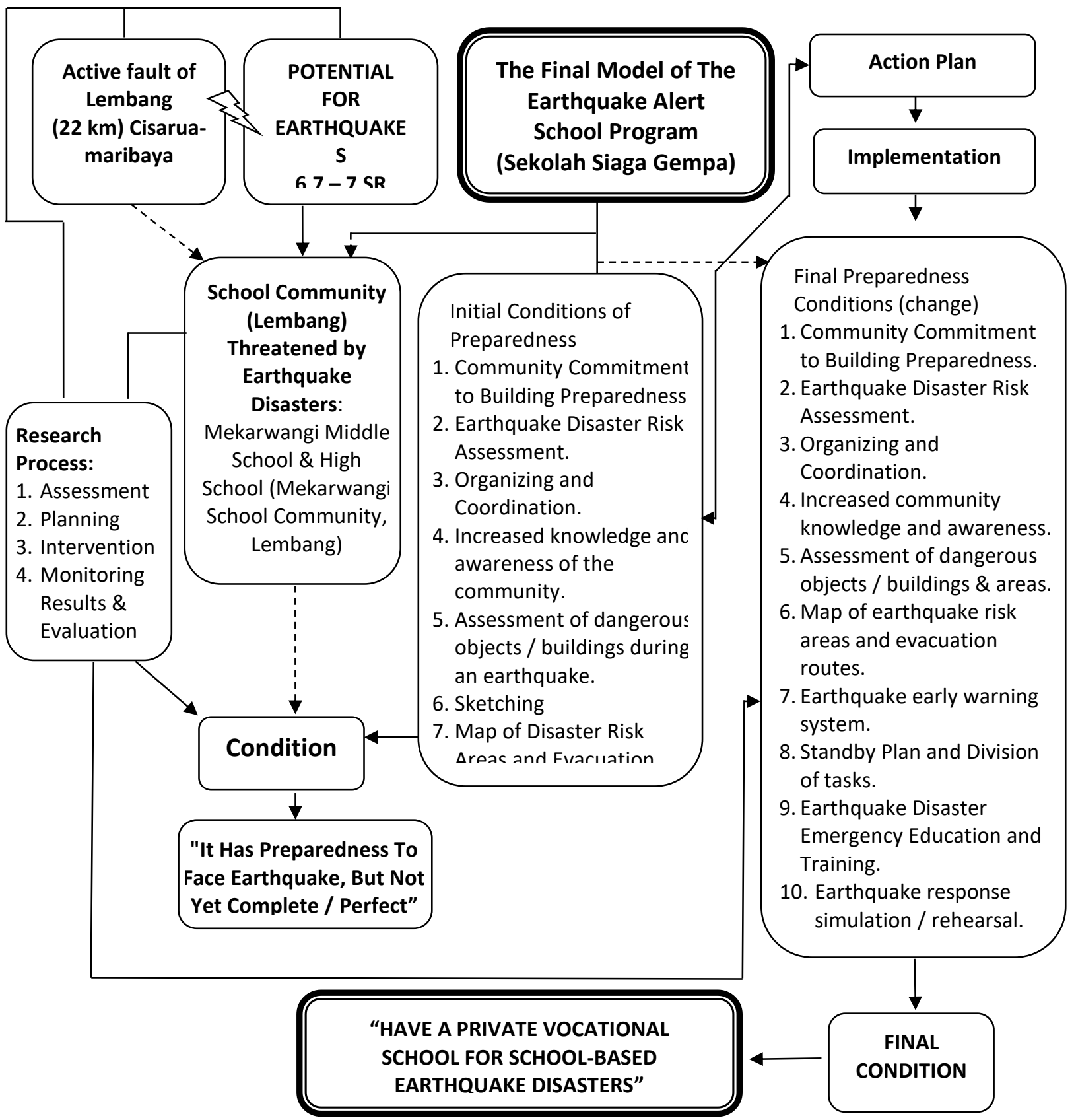




\section{Conclusion}

Disaster risk reduction efforts are pursued through increasing school-based preparedness that involves members of the school community, surrounding communities and various institutions that are associated with reducing the risk of school-based earthquake. There are several efforts to improve the understanding of the practice of school-based earthquake disaster risk reduction models / programs in school communities that are threatened by the potential for earthquake disasters due to the active fault of Lembang, Lembang District, West Bandung Regency, Indonesia. The disaster risk reduction program is wrapped up in a program name, namely the earthquake alert school (Earthquake Alert School). The Earthquake Alert School Program involves several schools that are threatened by the potential for earthquake disasters because they are above the active lembang fault line. The Earthquake Alert School Program focuses on efforts to increase the capacity of the community in facing the earthquake disaster, this aspect of capacity can also be categorized as an aspect of preparedness in the stages of disaster risk reduction.

\section{References}

Abarquez, Imelda, Murshed, Zubair. (2004). Community-Based Disaster Risk Management. Field Practitioners Handbook. Asian Disaster Preparedness Center (ADPC), P.O. Box 4, Klong Luang, Pathumthani 12120, Thailand

Adimihardja (dkk). 2003. Participatory Research Appraisal dalam Pelaksanaan Pengabdian Kepada Masyarakat. Bandung: Humaniora.

Affeltrenger, Bastian dkk. (2007). Hidup Akrab dengan Bencana. Sebuah Tinjauan Global tentang Inisiatif-inisisatif Pengurangan Bencana. Jakarta. MPBI.

Affeltranger (et.al.) 2006. Living With Risk, a Global Review of Disaster Reduction Initiatives. (Diterjemahkan oleh Theresia Wuryantari). Jakarta: MPBI.

Alih Bahasa Drs. Chatib MA, AjiWibowo dkk. Technique and Guidelines For Social Work Practice (Bradfor, W Sheaford, Charles R Horejsi, \& Gloria A Horejsi) Part IV: Chapter 10-14. (2006). Departemen Sosial RI. Badan Pendidikandan Penelitian Pusat Pendidikan dan Pelatihan Kesejahteraan Sosial.

Ali Soehatman. (2010). Pedoman Praktik Manajemen Bencana. Jakarta: Dian Rakyat Carter WN.

1991. Disaster Management. A disaster Manager's Handbook National

Library of ThePhiliphines CIP Data. Asian Development Bank.

Chaskin Robert. J (et al) 2001. Building capacity community. New York. Aldine de Gruyter

Djohani, Rianingsih dkk. (1996). Berbuat Bersama Berperan Setara. Bandung: Studi Driya Medika

Edi Suharto, (dkk), 2011. Pendidikan dan Praktik Pekerjaan Sosial di Indonesia dan Malaysia. Yogyakarta: Samudera Biru.

(2010). Membangun Masyarakat Memberdayakan Rakyat. Kajian Strategis

Pembangunan Kesejahteraan Sosial dan Pekerjaan Sosial. Bandung: PT.

Refika Aditama

Gutierrez, Parson, Cox.(2003). Empowerment in Social Work Practice.

Isbandi. R. Adi (2008). Intervensi Komunitas Pengembangan Masyarakat sebagai upaya Pemberdayaan Masyarakat. Jakarta: PT. Raja Grafindo Persada

Ife, Jim. Tesoriero, Frank. (2008). Community Development. Alternatif Pengembangan Masyarakat di Era Globalisasi. Jogjakarta: Pustaka Pelajar.

IDEP (2007), Panduang Penanggulangan Bencana Berbasis Masyarakat, seri Gempa Bumi. Bali: Yayasan IDEP

Jonatan Lassa, dkk. (2009). Pengelolaan Risiko Bencana Berbasis Komunitas (PRBBK). Jakarta: PT. Grasindo.

Kertapati, Engkon K. (2006). Aktivitas Gempabumi di Indonesia: Perspektif Regional Pada Karakteristik Gempabumi Merusak. Bandung: Pusat Survei Geologi

Kettner.M, dkk (1990). Designing and Managing Programs. An Effectiveness Based Approach. Newbury Park, London, New Delhi: Sage Publication

Kirst-Ashman, Karen.K, Hull, Jr, Grafton. H. (2006). Understanding Generalis Practice. Thomson Brooks/Cole.

Mc Donald, G.A. (1972). Volcanoes. New Jersey. Prentice Hall. INC. Englewood Cliffs

Moleong, Lexy. J. (2010). Metodologi Penelitian Kualitatif. Bandung: PT. Remaja Rosdakarya.

Morris, Teresa. (2006). Methods Research Social Work. Four Alternative Paradigms. Sage Publication. Thousand Oak. London. New Delhi. 
Nurjanah, dkk (2012). Manajemen Bencana. Bandung: Alfabeta.

Payne, Malcom (2005). Modern Social Work Theory. New York: Palgrave Macmilan.

Pincus, Allen (et.al.) 1974. Social work practice : Model and method. University of Wisconsin, Madison. Itasca, Illinois : F.E. Peacock Publishers, Inc.

PujiPujiono, (ed). (2006). Kampanye Dunia Pengurangan Bencana: Pengurangan Risiko Bencana Dimulai di Sekolah. Jakarta: Masyarakat Penanggulangan Bencana Indonesia (MPBI)

Queralt, Magaly. The Social Environment and Human Behavior a Diversity Perspective. (1996). A. Simon \& Schuster Company Needham Heightt Mass.

Rothman, Jack, Tropman, John. E. (1974). Strategies of Community Organization. A Book of Reading. Second Edition. Itasca. Illinois. . F.E. Peacoek.

Syarif Muhidin. (2011). Perencanaan Sosial. Bandung: STKS Press Bandung

Soerjono Soekanto (Ed.) 1987. Sosiologi Suatu Pengantar. Jakarta: PT. Raja Grafindo Persada.

Streeter, Calvin.L, Murty, Susan.A. (1996). Research on Social Work Disaster. The Hayworth Press, Inc.NewYork.London

Sugiyono. (2011). Cet.13. Metode Penelitian Kuantitatif, Kualitatif dan Research And Development $(R \& D)$. Bandung: Alfabeta.

Heru Dwi Sukoco, (Ed.) 1991. Profesi Pekerjaan Sosial dan Proses Pertolongan. Bandung: Kopma STKS

-------- (1991). Profesi Pekerjaan Sosial dan Proses Pertolongannnya. Bandung: Koperasi STKS.

Syafrezani, Sampaguita. (2010). Tanggap Bencana Gempa Bumi. Bandung: Angkasa.

Streeter, Calvin. L, Murty, Susan. A. (1996). Research on Social Work Disaster. The Hayworth Press, Inc. New York. London

Ulber Silalahi, (2006), Metode Penelitian Sosial; Unpar Press; Bandung.

Tukinodan Suhendar. (2009). Strategi Pengurangan Risiko Bencana. Bandung: STKS Press.

Conflicts of Interest: The authors declare no conflict of interest. 


\section{References}

Bab`cák, Vladimír. 2008. Dane a Danov é Právo na Slovensku I. (Taxes and Tax Law in Slovakia I.). Košice: Aprilla s.r.o.

Bab`cák, Vladimír. 2015. Danov é Právo na Slovensku (Tax Law in Slovakia). Košice: Epos.

Barancová, Helena. 2012. Základné Práva a Slobody v Pracovnom Práve (Basic Rights and Freedoms in Labor Law). Plzen: Aleš Ceňek.

Barinková, Milena. 2007. Sociálna Ochrana Zamestnancov so Zodpovednost'ou za Rodinu (Social Protection of Employees with Family Responsibilities). Košice: Pavol Josef Safarik University of Kosice.

Batrancea, Larissa Margareta, and Ramona Anca Nichita. 2012. Tax compliance models: From economic to behavioral approaches. Journal Transylvanian Review of Administrative Sciences 36: 13-26.

Beblavý, Miroslav. 2009. Sociálna Politika (Social Policy). Bratislava: ADIN, s.r.o.

Bílý, Jǐrí, and Zuzana Horváthová. 2016. Personal security and social care: A comparison of Germany and the Czech Republic. Journal of Security and Sustainability Issues 6: 104-20. [CrossRef]

Bruun, Niklas, Klaus Lorcher, Isabelle Schomann, and Stefan Clauwaert. 2017. The European Social Charter and Employment Relation. Oxford: Hart Publishing.

Bujn áková, Mária. 2006. Princípy a zásady v danovom práve (Principles and fundamental in tax law). In Aktuálne Otázky Práva. Košice: Pavol Josef Safarik University of Kosice, pp. 159-69.

Dagan, Tsilly. 2017. International Tax and Global Justice. Journal Theoretical Inquiries in Law 18: 1-35. [CrossRef]

Dolado, Juan, Francis Kramarz, Stephen Machin, Alan Manning, David Margolis, Coen Teulings, Gilles Saint-Paul, and Michael Keen. 1996. The Economic Impact of Minimum Wages in Europe. Economic Policy. Available online: http://www.jstor.org/stable/1344707 (accessed on 12 March 2018). [CrossRef]

Eurostat. 2017. Minimum Wage. Available online: http://ec.europa.eu/eurostat/statistics-explained/index.php/ Minimum_wage_statistics/sk (accessed on 10 February 2018).

Fabo, Brian, and Sharon Sarah Belli. 2017. (Un) Beliveable Wages? An Analysis of Minimum Wage Policies in Europe from a Livingwage Perspective. IZA Journal of Labor Policy. [CrossRef]

Horváth, Peter. 2017. Miestne referendum ako nástroj demokracie—Skuto`cná demokracia (Local referendum as a tool of democracy—A real democracy?). In Formy Uskuto`cnovania` Obecnej Samosprávy. Košice: Pavol Josef Safarik University of Kosice, pp. 71-80.

Horváthová, Zuzana. 2016. Social Systems and Policies. Praha: MUP Press, p. 124.

Jakubek, Peter, Juraj Tej, Daniel Laǰcin, and Gabriela Gabrhelová. 2016. Perception of the reform of the tax system in the Slovak Republic by business entities and financial administration. Journal of Economics 64: 751-67.

Jovanovi'c, Tatjana, and Maja Klun. 2017. Tax policy assessment in Slovenia-Case of interest tax shield. Journal DANUBE: Law and Economics Review 8: 1-17. [CrossRef]

Juřcíková, Vilma. 2008. Nerovnost’ a jej Nové Dimenzie v ére Globalizácie. Bratislava: Ekonomický ústav SAV.

Katz, Harry C. 2018. Public Service Management and Employment Relations in Europe: Emerging from the Crisis. Journal ILR Review 71: 554-55. [CrossRef]

Kogan, Vladimir. 2017. Do Anti-Union Policies Increase Inequality? Evidence from State Adoption of Right-toWork Laws. Journal State Politics \& Policy Quarterly 17: 180-200.

Králik, Jozef, and Daniel Jakubovǐc. 2004. Financné Právo (Financial Law). Bratislava: Veda.

Králik, Jozef, L’ubomír Grún, and Ladislav Balko. 2001. Základy Danoveého, Poplatkového a Colného Práva (Fundamentals of Tax, Fee and Customs Law). Bratislava: Comenius University.

Krebs, Vladimír. 2005. Sociální Politika (Social Policy). Praha: ASPI, a.s.

Krunková, Alena. 2007. Aproximácia Právneho Poriadku Slovenskej Republiky so Systémom Práva Európskej Únie (Vybrané Problémy) (Approximation of the Legal Order of the Slovak Republic with the System of European Union Law (Selected Problems)). Ob`can a Verejná Správa. Košice: Pavol Josef Safarik University of Kosice.

Lenhart, Otto. 2017. The impact of minimum wages on population health: Evidence from 24 OECD countries. European Journal of Health Economics 18: 1031-39. [CrossRef] [PubMed]

Macková, Zuzana. 2008. Inštitút Minimálnej Mzdy—Prežitok Alebo Nevyhnutnost' 3. Tisícro`cia? (Minimum Wage Institute-Experience or Necessity of the 3rd Millennium?). Brno: Pracovní Právo, Available online: https: //www.law.muni.cz/sborniky/Pracovni_pravo2008/files/mackova.html (accessed on 15 December 2017).

Mihalik, Jaroslav. 2015. Political Legacy and Youth Civic Engagement in Slovakia. Novo Mesto: Faculty of Organization Studies. 
Molitoris, Peter. 2008. Relatívna Danov`á Suverenita Obce v Kontexte Realizácie Sociálnej Politiky Samospráv. (Relative Tax Sovereignty of the Municipality in the Context of Realization of Social Policy of Municipalities). Znojmo: Zborník Metamorfózy práva ve sťrední Evrop`e.

Muller, Adolf. 1991. Úvod do Vedy o Politice (An Introduction to Politics). Praha: LUNARION.

Oh, Jason S. 2017. Are progressive tax rates progressive policy? New York University Law Review 92: $1909-76$. Ondruš, Branislav, Ivana Štefánková, Peter Líška, and Tomáš Kramer. 2017. Minimálna Mzda-Empirické Zistenia Kontra Ideologické Mýty. Available online: https://www.ia.gov.sk/data/files/NP_CSD_II/Analyzy/Stat/ Myty_a_fakty_o_minimalnej_mzde.pdf (accessed on 13 April 2018).

Pavelka, Tomáš, Marek Skala, and Jan Cadil. 2014. Selected issues of the minimum wage in the Czech Republic. E \& M Ekonomie a Management 17: 30-45.

Pernica, Martin. 2016. Conditions of minimum wage indexation in Czech and Slovak legislation in the context of business economics. Journal DANUBE: Law and Economics Review 7: 243-58. [CrossRef]

Rievajová, Eva. 2006. Sociálne Zabezpe cenie (Social Security). Bratislava: Sprint.

Terell, Paul, and Neil Gilbert. 2012. Dimensions of Social Welfare Policy. Cambridge: Pearson Publishing. Tomandl, Theodor. 1994. Der Einau sozialer Grundrechte in das positive Rech, Recht und Staat in Geschiste und

Gegenwart, Tubingen 1971. In Ústavnoprávne Problémy Sociálnych Práv v Pracovnoprávnych Vzt'ahoch. Edited by Barancová Helena. Bratislava: SPRINT 2 s.r.o.

Uhrová, Natalie, and Petr Skalka. 2016. The impact of minimum wage changes in the Czech republice. Journal DANUBE: Law and Economics Review 7: 183-89.

Žof cinová, Vladimíra. 2010. Sociálny Status Ob`cana v Kontexte Právnej Úpravy Zdanovania` Prîmov Fyzických Osôb 